\title{
3D Reconstruction as a Form of Interpretation: Example of Excavation of the Medieval Pet'uša Castle (Central Slovakia)
}

\author{
Matej Styk ${ }^{\mathrm{a}^{*}}$, Noémi Beljak Pažinováa \\ ${ }^{a}$ Department of Archaeology, Constantine the Philosopher University in Nitra, Tr. A. Hlinku 1, Nitra, Slovakia.
}

\section{ARTICLE INFO}

\section{Article history:}

Received: $2^{\text {nd }}$ March 2020

Accepted: $7^{\text {th }}$ July 2020

DOI: http://dx.doi.org/10.24916/iansa.2020.1.6

Key words:

3D technology

visualization

archaeological excavation

High Middle Ages

Pet'uša Castle

Central Slovakia

\begin{abstract}
A B S TR ACT
The paper presents a case study from the research of the High Medieval Pet’uša Castle (Zvolen District) in Central Slovakia. Its aim is to present documentation and analytical procedures based on the application of 3D techniques in archaeology. During the archaeological excavation of the Pet'uša Castle, several methods were used to document the castle hill, archaeological contexts and artefacts. The aim of the paper is to reference the possibilities of $3 \mathrm{D}$ visualization, which serves not only as an interesting presentation of archaeological results to the general public, but also for the work of the archaeologists themselves. The primary goal is to use 3D technology in the analysis and subsequent interpretation in a way that is not common in archaeological procedures. These methods are applied in the interpretation of the architecture of the castle, walking ground level and the surrounding environment. The main contribution is the clarification of spatial relations, visualization of the examined structures, and the opening of polemics within the interpretation levels.
\end{abstract}

\section{Introduction}

In Slovakia in recent years there has been a great number of excavations of castles from the Middle Ages or Modern Era. The main priority of these excavations has been the restoration and reconstruction of the preserved architecture; in other words, the conservation of the torsional parts of structures (for details, see Herceg and Mazúr, 2018). Only a very small number of castles are being solely excavated for scientific and documentation purposes, for example, with its primary focus being the revealing of our forgotten history. The ruins of the Pet'uša Castle (cadastre of Ostrá Lúka) near Zvolen in Central Slovakia can serve as an illustrative example (Figure 1). During eight excavational seasons (2011-2018) the castle has undergone an interdisciplinary research under the leadership of the Department of Archaeology, Constantine the Philosopher University in Nitra. No written or iconographic sources are known for this site (Beljak Pažinová and Ragač, 2018). Therefore, the period name of the castle or who built the castle, in other

\footnotetext{
*Corresponding author. E-mail: mstyk@ukf.sk
}

words its owner, is unknown. The castle was discovered by terrain reconnaissance (the visible massive destruction mound of the stone curtain wall in forest vegetation) and by the initial field survey (Figure 2) on the site (Hanuliak, 2006, p.265). The current name of the castle ruins originates from the name of the nearby location of Pet'usa (a meadow situated northwest of the castle), which is marked on all basic topographic maps.

The castle is situated on the top of a small hill over the left riverbank of the Gran (Hron) River and approximately $6 \mathrm{~km}$ away from the city of Zvolen. It is $2 \mathrm{~km}$ distant in visual contact with the well-known, medieval, royal Pustý (Deserted) Castle (Beljak, et al., 2014; Beljak, Beljak Pažinová and Šimkovič, 2018, pp.5-62), towering over the city of Zvolen. Pet'uša Castle has an oval shape with maximum dimensions of $44 \times 22 \mathrm{~m}$ and it is situated in a north-south direction with an altitude of its interior space of 368-372.7 $\mathrm{m}$ asl. From the north, east and west side, the castle is protected by steep cliffs. The south to southeast side of the castle had been protected by a massive defensive ditch carved into the bedrock, which even today is still nearly 14 metres deep. Two terraces are situated over the ditch from the south side. The distance between these 


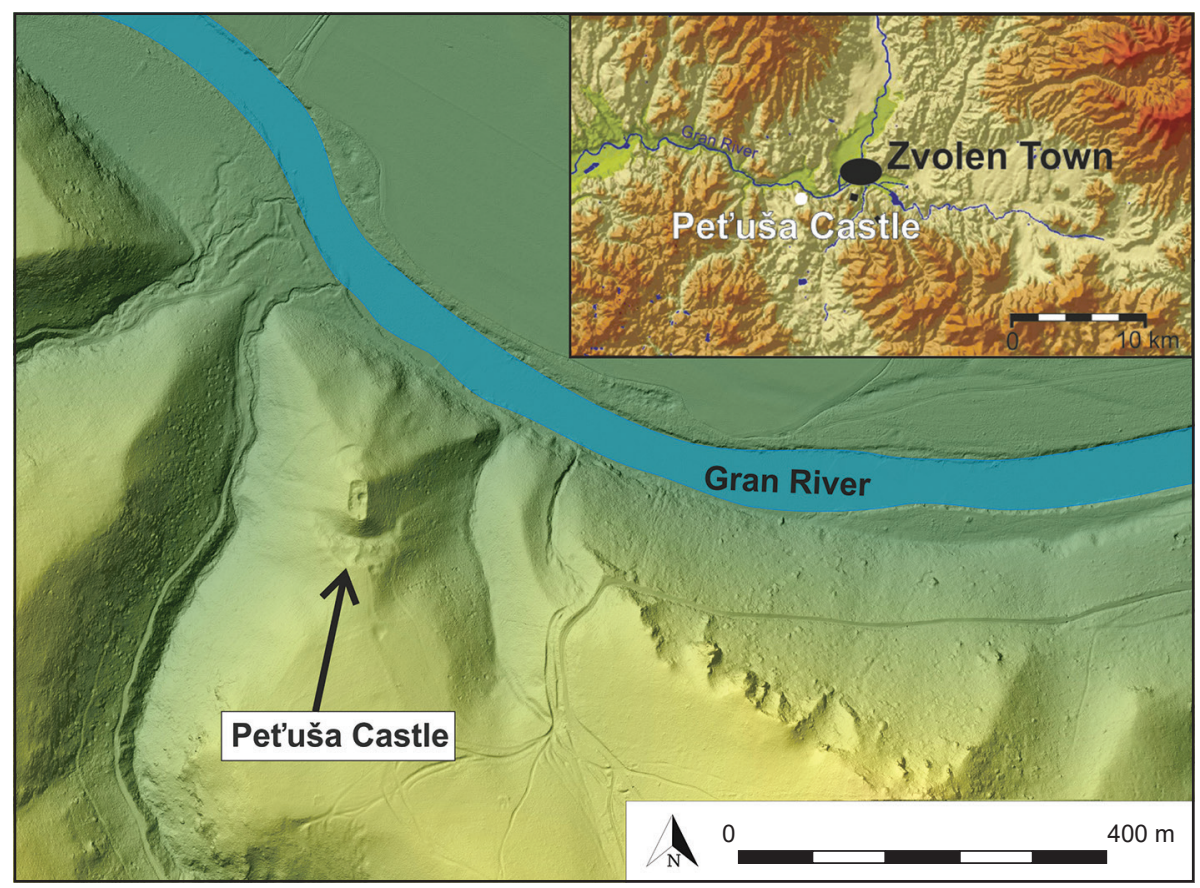

Figure 1. Pet’uša Castle, Zvolen District, Slovakia. Castle location in the vicinity of Zvolen Town above the Gran (Hron) river. Source: LIDAR by National Forest Center Zvolen (2018).

terraces and the south side of the castle is ca. 40 metres (in shortest direct line).

The location of the Pet'uša Castle - on a ridge in a narrow valley above the flow of the Gran River with a good view over the southern part of the Pliešovská basin (and thus the northwest part of the historical Zvolen county) - leads us to the logical assumption that this castle served as a guard post with its main task to control the local roads and waterways. This assumption is supported by its location in the near vicinity of a medieval ford on the Gran River, called Szellösrév (Maliniak, 2009, pp.216-218), closely beyond the edge of the medieval Zvolen land area, whose citizens had been freed from paying tolls throughout the Kingdom of Hungary (Ragač, 1998, pp.13-14). The castle is also located near old pathways (and former stopping points) used as trade roads (represented by visible carriage marks) leading from the south (from Pliešovská basin) to the town of Zvolen (Pažinová, et al. 2013, p.160, pic. 4 and 8; Slamová, et al., 2014; 2016). From the crossroads of trade

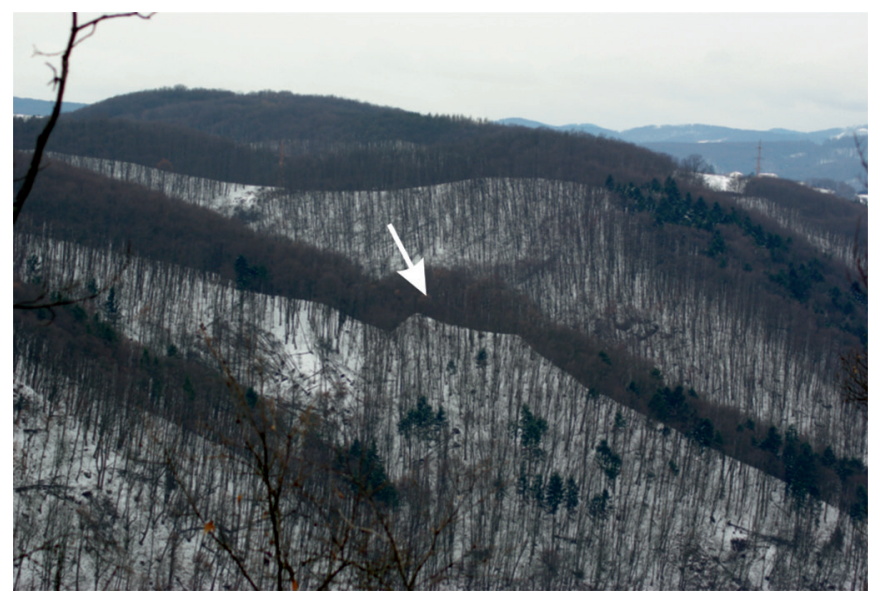

roads located $450 \mathrm{~m}$ away from Pet'uša Castle, a possible access path leads to the southern terrace above the castle ditch, the path being identified with the use of datasets from a point cloud obtained from the scanning technology LiDAR (light detection and ranging; source: National Forest Centre Zvolen, average height $700 \mathrm{~m}$ ).

The main goal of the Pet'uša Castle excavation is to uncover the process of its construction and the subsequent use of the area, including the functional division of interior space. Among the main research questions belong the finding of its functionality, the duration and usage of the castle, and its involvement in an historical context. This article aims to point out the possibilities of using 3D technology for the analysis and subsequent interpretation of the Pet'uša Castle disposition. The main focus of attention is the castle complex itself and the surrounding contemporary environment. The intention is one of greater understanding, clarification of spatial relations and a visualization of the studied structures by means of $3 \mathrm{D}$ documentation, and the reconstruction of

Figure 2. Pet’uša Castle, Zvolen District, Slovakia. Castle Hill Profile (view from the east) and an aerial view of the castle courtyard. Photo by Jan Beljak. 
the original space and simulation of its individual stages of construction.

In just the last 15 years, archaeology has seen a growth in 3D-technology usage (see Barceló, 2000, pp.9-36). To a large extent, usage of these procedures is linked to the documentation of the archaeological situations and findings at a level of higher quality (e.g. Forte, 2010, pp.9-14). The 3D results themselves, whether based on scanning or photogrammetry, are commonly used within interpretative procedures (e.g. Callieri, et al., 2011), or as an expansion of the documentation methods used. In addition, the analytical meaning of this $3 \mathrm{D}$ technology is gradually going forward, where the focus is on different forms of spatial measurements (e.g. Dellepiane, et al., 2013, pp.201-
210). An extension of these procedures is $3 \mathrm{D}$ visualization, not only involving the presentation of the results but also serving the purpose of the research itself, just as it is used in the analysis of visibility, light and composition (e.g. Forte, 2008; Gruber, 2015, pp.63-68; Paliou, 2014, pp.91-113). At the same time, it is being enhanced with exact geographical and qualitative attributes through GIS (e.g. Aspöck and Fera, 2015, pp.2-8; Garstki, et al., 2015, pp.23-30). One remaining challenge is the discernment of time changes and the better application of natural laws in 3D simulations. 3D space can allow for the better archaeological reconstruction of an assemblage of finds and highlight spatial relations, as well as time determinism, within a broad archaeological context.

Figure 3. Petuša Castle. Disposition of trenches in the castle hill with an elevation model. Green polygons show trenches which were 3D documented using Structure from Motion. Blue lines mark interpreted structures: A - keep, B - structure with stone fundament, $\mathrm{C}-$ water tank, $\mathrm{D}+\mathrm{E}-$ first phase structures, $\mathrm{F}-$ second phase structure.

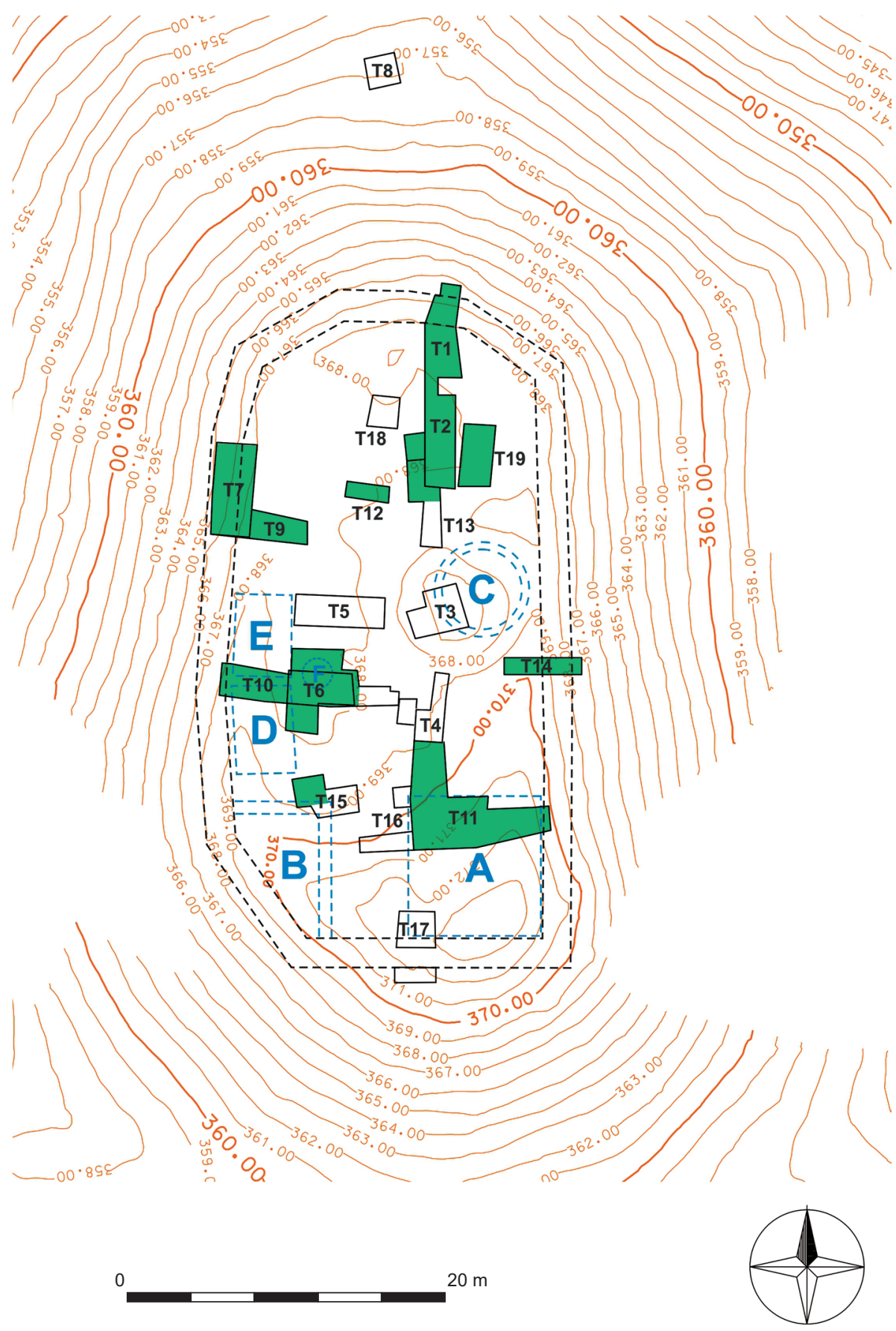




\section{Background}

The first excavation of Pet'uša Castle was carried out in 1997. It was a short one-day prospection of the castle courtyard combined with a field and metal-detector survey (Hanuliak, 2006). At that time, a vast deep rectangular feature with dimensions of $9 \times 8 \mathrm{~m}$ was visually identified, which was interpreted as the cellar of the former residential tower within the castle area. Currently, we know that the castle water-tank cistern was located there. Hanuliak (2006, p.265) also assumed that a metre thick, stone fortification was positioned only on the south side of the castle, situated above the ditch, and that the remaining sides were composed of only a wooden palisade. Gathered finds from the courtyard were primarily dated to the second half of the $15^{\text {th }}$ century and were assumed to be related to the period associated with the activity of Jan Jiskra and his army in the Zvolen area, or more precisely in central Slovakia.

A systematic archaeological excavation began during the summer season of 2011. Before the beginning of the excavation, in 2010, a geophysical measurement with the use of a Fluxgate magnetometer (Sensys Technology GmbH) took place at the castle courtyard (on three polygons). The purpose of the measurement was to find out the range and depth of solid materials (stone building foundations, debris, etc.), the occurrence of hollow spaces, as well as information regarding orientation in respect to cardinal points and its dimensions. There were plenty of anomalies recorded in the castle courtyard (at a depth as little as $0.5 \mathrm{~m}$ below the present surface). But it was not possible to distinguish whether the remains were related to stone foundations or debris. The geophysical research did not bring the expected result of confirming the existence of stone structures and walls within the castle area. Therefore, research methodology from 2011 onwards focused more on the gradual uncovering of the castle courtyard using a grid-square-system method. The entire castle area was divided into 200 sectors with one square/ sector being $2 \times 2 \mathrm{~m}$. The sectors strictly maintained an eastwest and north-south orientation. Each sector was examined according to its individual selection as regarding terrain configuration, an assumption of its situation for important findings, as well as randomly. The main intention was to gain the most integral north-south and east-west profile of the castle courtyard including the peripheral (curtain) wall. During eight research seasons, 19 archaeological trenches (Figure 3) were excavated in the castle grounds. Gradually, the parts of the massive stone peripheral walls and several courtyard spaces were uncovered, where the remains of clay-wood and stone architecture were identified (Beljak Pažinová, 2017). Overall, an area of more than $150 \mathrm{~m}^{2}$ has been examined. The vast find assemblage from the castle consists of ceramic fragments (more than 30,000 pieces), animal bones (more than 7000 pieces), metal finds (close to 2200 items), and other important finds. Based on its rich material culture, the dating of the castle has been made more accurate. Its construction is associated with the end of the $13^{\text {th }}$ century and its downfall can be dated to the turn of the $15^{\text {th }}$ to $16^{\text {th }}$ century. Its greatest flourish is apparent in the $14^{\text {th }}$ and first half of the $15^{\text {th }}$ centuries, when the castle was gradually rebuilt and purposefully used.

From the point of view of the castle's function during the High Middle Ages, it is logical to assume that besides its strategical and guarding position, it was responsible for toll collection. The medieval toll station tributum in Ostra Lúka was documented for the first time in 1393 (privilege list of the monarch Sigismund of Luxembourg) and it was being mentioned in written sources even later (1412, 1424, 1478, and lastly 1519). This royal toll station was a property of the castle estate of Dobrá Niva Castle (Beljak Pažinová and Ragač, 2018) and serviced the merchants travelling to markets in Zvolen. Even though information about this toll station in medieval writing is very scarce, its exact location thus being unknown, the convenient position of the Pet'uša Castle could have played an important role in the defence of the toll station.

\section{Method of documentation}

Documentation of archaeological contexts continued throughout every phase of the excavation in the standard way with the use of drawing and photographic records. During the 2015 season, an altitude survey of the site was made (with the use of a total station - by company ORNTH). Thanks to this survey, a contour line plan and, later, an elevation model of the relief could be made.

Separate from this documentation was the creation of $3 \mathrm{D}$ models of the terrain situations and stone parts, with the use of a picture correlation method - Structure from Motion (Hirschmuller, 2008, pp.328-341). This form of photogrammetry was performed over three seasons from 2016 to 2018. Thanks to this, 12 trenches (Figure 3 - green polygons) and 17 separate 3D models were documented (1-1.5 M polygons with a texture resolution up to $10 \mathrm{~K})$ as well as 13 architectural parts (100-150 K polygons with a texture resolution up to $4 \mathrm{~K}$ ). Data collection methodology was set up with the purpose of using Agisoft PhotoScan processing. This method used different types of cameras: a Nikon D3300 (13.5 Mpx) and a Nikon D7200 (24 Mpx). In the case of pictures taken by the D3300, pictures had to be calibrated due to barrel distortion (edited in Photoshop - through lens correction).

During the first season (pictures taken with the Nikon D3300) a precise collection method was used for more effective program processing. For every situation, a photo sheet was made with basic localization data, lighting conditions, lens focal length, ISO value, WB (white balance) setting, and time the picture was taken. At the same time, total proportions, orientation of features and used markers (M1-4) were documented, for the realistic dimensions of 3D models. Considering the measurement limitations of GPS in forest terrain, absolute dimensions between markers had to be taken right at each place. For a more effective processing of data, pictures were taken in different resolutions: as data for geometry $(4 \mathrm{~K}=\mathrm{ca} .8 \mathrm{MB} / \mathrm{image})$ and for 


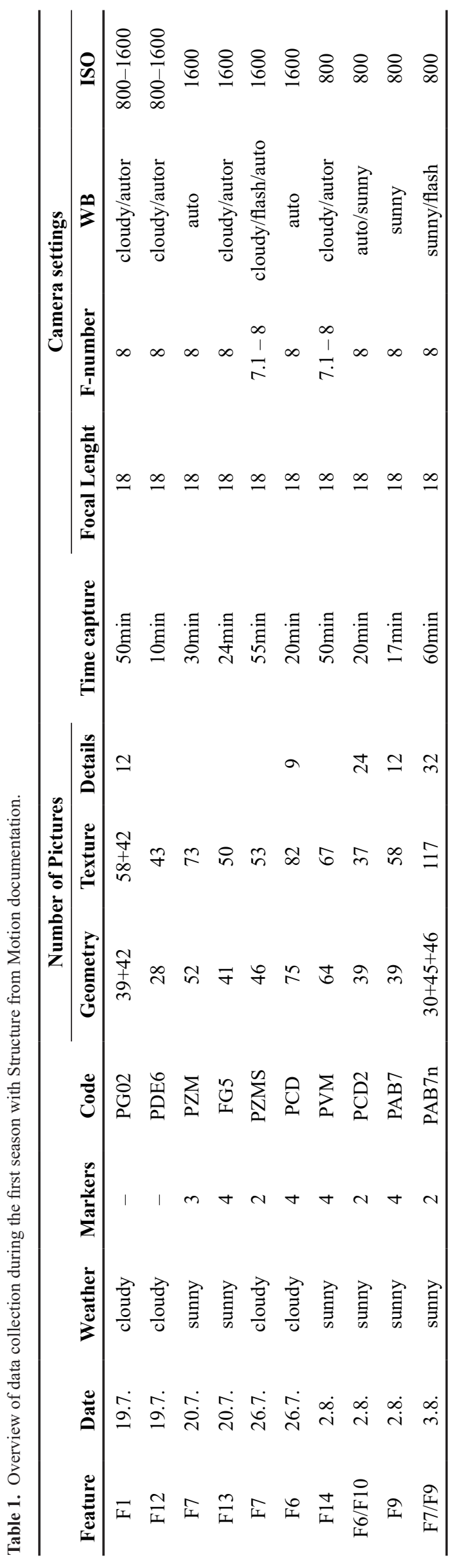

textures $(6 \mathrm{~K}=$ ca. $14 \mathrm{MB} /$ image $)$. Within every single model, a total number of pictures were tracked for geometry, texture and additional details (Table 1).

The creation of 3D models in Agisoft is based on a step by step process: 1 . align photos; 2 . build dense cloud; 3 . build Mesh; 4. build texture. In term of hardware difficulty, the CPU was heavily loaded mainly by the $1^{\text {st }}, 3^{\text {rd }}$ and $4^{\text {th }}$ step, while the GPU was mainly loaded by the $2^{\text {nd }}$ step. In both cases, the quality of the components is reflected only in the amount of time required for a single calculation. Thus, the factor of a limitation in the size of RAM will show up in the $3^{\text {rd }}$ step of creating geometry. The efforts of the different approaches of documentation of the find assemblages were to prepare the appropriate data for the creation of a solid geometry and detailed pictures for the creation of texture with a high resolution. It is important to note that in both cases the optical settings of the camera were not altered. The only difference was the quality (resolution) of the pictures taken. Therefore, a "chunk" consisted of several photo folders (geometry, texture, details). All photos were used in step 1, while steps 2 and 3 consisted of photos from the geometry folder, and step 4 used photos from the texture and details folder. The somewhat longer process of terrain documentation enabled faster machine processing with fewer resource demands (especially size of RAM - 8GB) and better results.

The following digitalization of the documentation was carried out in two steps. The first step was a 3D reconstruction of the assemblage of finds. Based on the spatial survey of the castle hill relief, a contour plan with absolute heights was made by the ORNTH company. Subsequently, the contour plan was filtered by the AutoCAD Civil 3D program (processes: purge, overkill) into one layer and exported in the .dwg format to the $3 \mathrm{ds}$ MAX program. The contour spline object was transferred through the plugin compount:terrain and populate:terraine into a $3 \mathrm{D}$ mesh object. The resulting model was in a scale of 1:1 with relative sea level elevation (unfortunately the Lidar data were only available later). The model was given texture in the ground plan form of the construction-history interpretation (Šimkovic, 2018, plane 1). The result was a 3D castle ground plan, a relief, and the positioning of individual archaeological trenches (Figure 4).

Subsequently, the 3D models were implemented. With the help of image correlation, 17 models were created in the AgiSoft PhotoScan program. Since the creation of the models used absolute dimensions, a change of scale in the common working environment was unnecessary. Separate models were implemented into the terrain based on the geodetic measurements of the trenches' dimensions. All 17 models captured 8 archaeological trenches in the area of the castle hill. The different count of 3D models and archaeological trenches was caused by the documentation of the $6^{\text {th }}, 7^{\text {th }}$ and $9^{\text {th }}$ trenches being in multiple phases (Figure 5). Based on this documentational approach, we were able to work with multiple levels of excavation, and using this method capture separate contexts in different time horizons. In order 


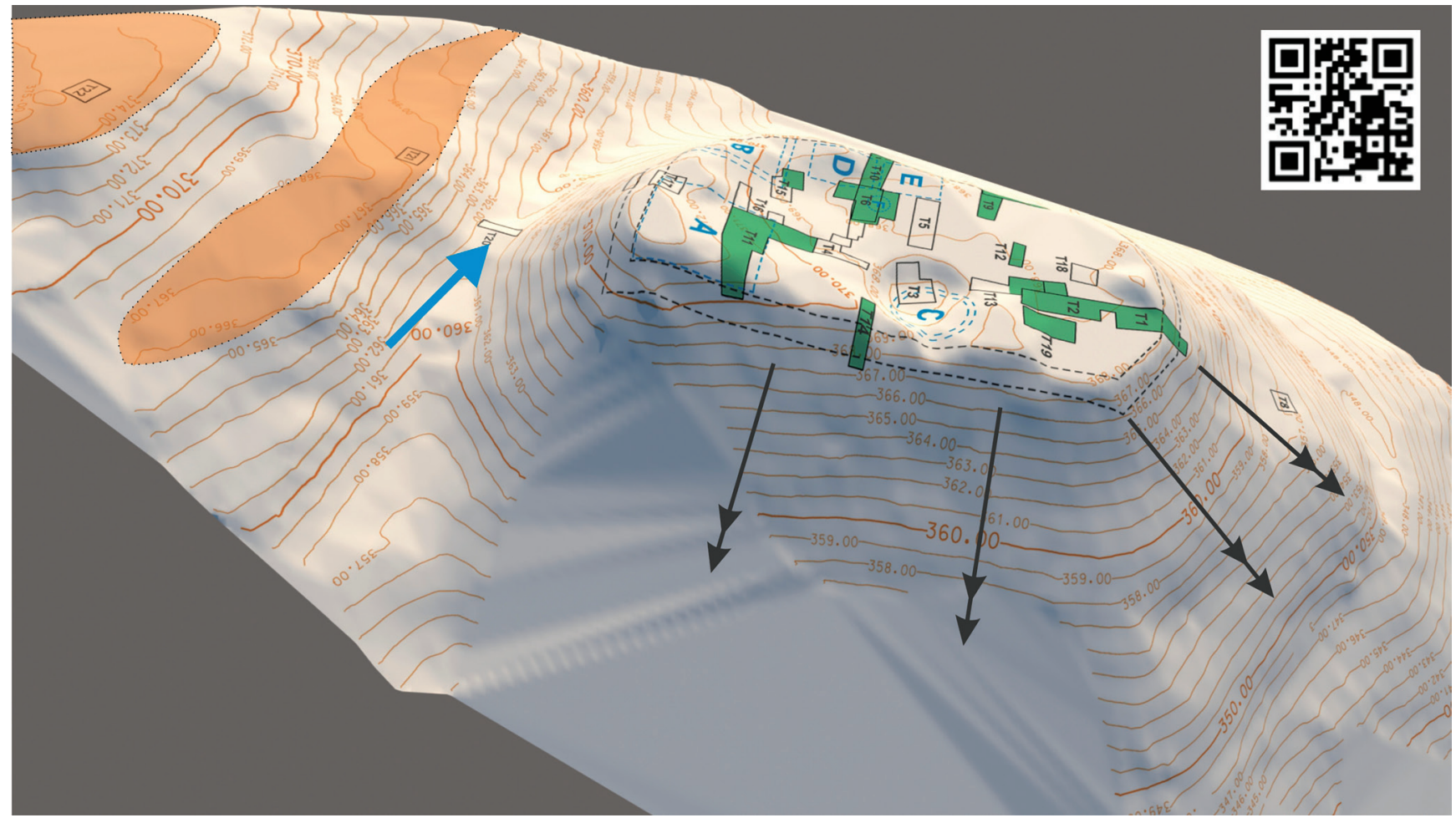

Figure 4. Reconstruction of finding assemblage. 3D model of current terrain with construction-history interpretation (southwest view). In the model there are upper and lower terraces highlighted by orange surfaces, a defensive ditch by a blue arrow, and a steep northern slope descending to the River Gran by black arrows. QR code to Sketchfab model.

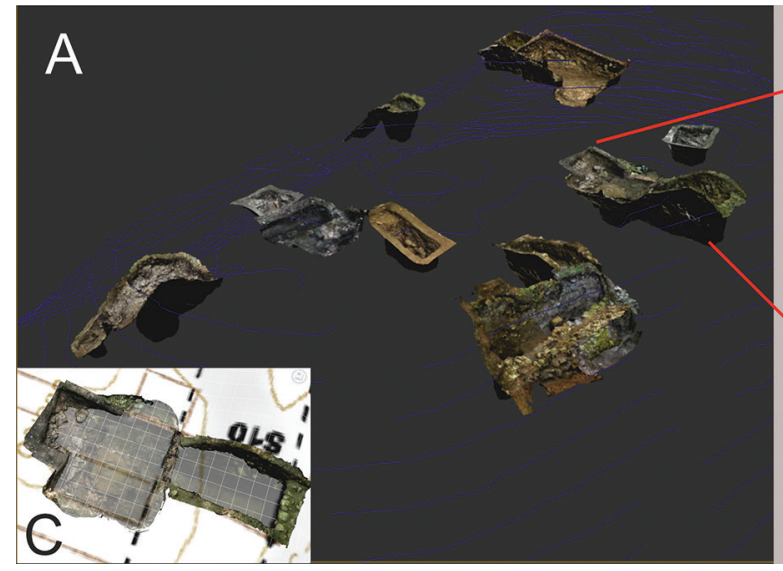

to realize post-ex archaeological excavation in 3D space $(3 \mathrm{ds}$ MAX software), models from each phase of documentation were combined into one-unit corresponding to a given trench. The means of precise overlay opened up the possibility of applying new stratigraphic cuts, and adjusting the stratigraphic sequence or context expansion. From the qualitative point of view, there arose the problem of textures with different settings of WB (white balance), which was caused by different lighting conditions during the excavation.

\section{3D reconstruction}

\subsection{Original terrain}

The reconstruction of the original ground terrain represents a process connected with an inverse archaeological
Figure 5. Digitalization of the finding assemblage. A: Implementation of 3D models of trenches into the spatial layout of the castle (southeast view). B: method of multiphase documentation based on the example of trench no. 6 and 10. C: trench fitting into the current terrain with the use of markers. transformation. However, 3D reconstruction has its specific points, which need to be emphasized. The starting point is the digitalized find assemblage, represented by the spatial relationship between the current terrain and the $3 \mathrm{D}$ models of the archaeological trenches. Every single model of a trench captures some stratigraphic relationships of individual contexts during the multiple phases of the excavation. Within individual trenches, based on their find assemblage, other stratigraphic units were found that could be attributed to the walking ground level in different time periods of the castle's occupation. Furthermore, each trench was specified not only by its stratigraphic levels but also by the bedrock. Thus, the reconstruction of the original terrain is based on the identification of the so-called walking ground levels (level 1-3) within each archaeological trench. Detailed $3 \mathrm{D}$ models of the trenches made it possible to implement 
Figure 6. Terrain Level Determination in the example of trench no. 1. A: Level 1 modelled terrain with highlighted blue contour lines and the location of individual trenches and stratigraphic levels (northeast view). B: example of levelling in trench no. 1. C: west section of trench no. $1-\mathrm{a}$ : stone rim of the unaligned foundation of the wall, b: inner-facing wall of north fortification (stratigraphic units: 1 bedrock; 2 - strongly compacted, brown clay into which the unmatched foundation of the wall is founded = period of construction of the fortification; 3 - compacted, solid brown layer $=$ level $1 ; 4-$ light black, compacted clay layer extremely rich in findings $=$ level 2; $5-$ light-brown clay layer attached to the above-ground face of the wall $=$ level 3;6- light-grey layer of sharp-edged quarry stone $=$ destruction of fortifications; 7 - black-grey layer of forest humus).
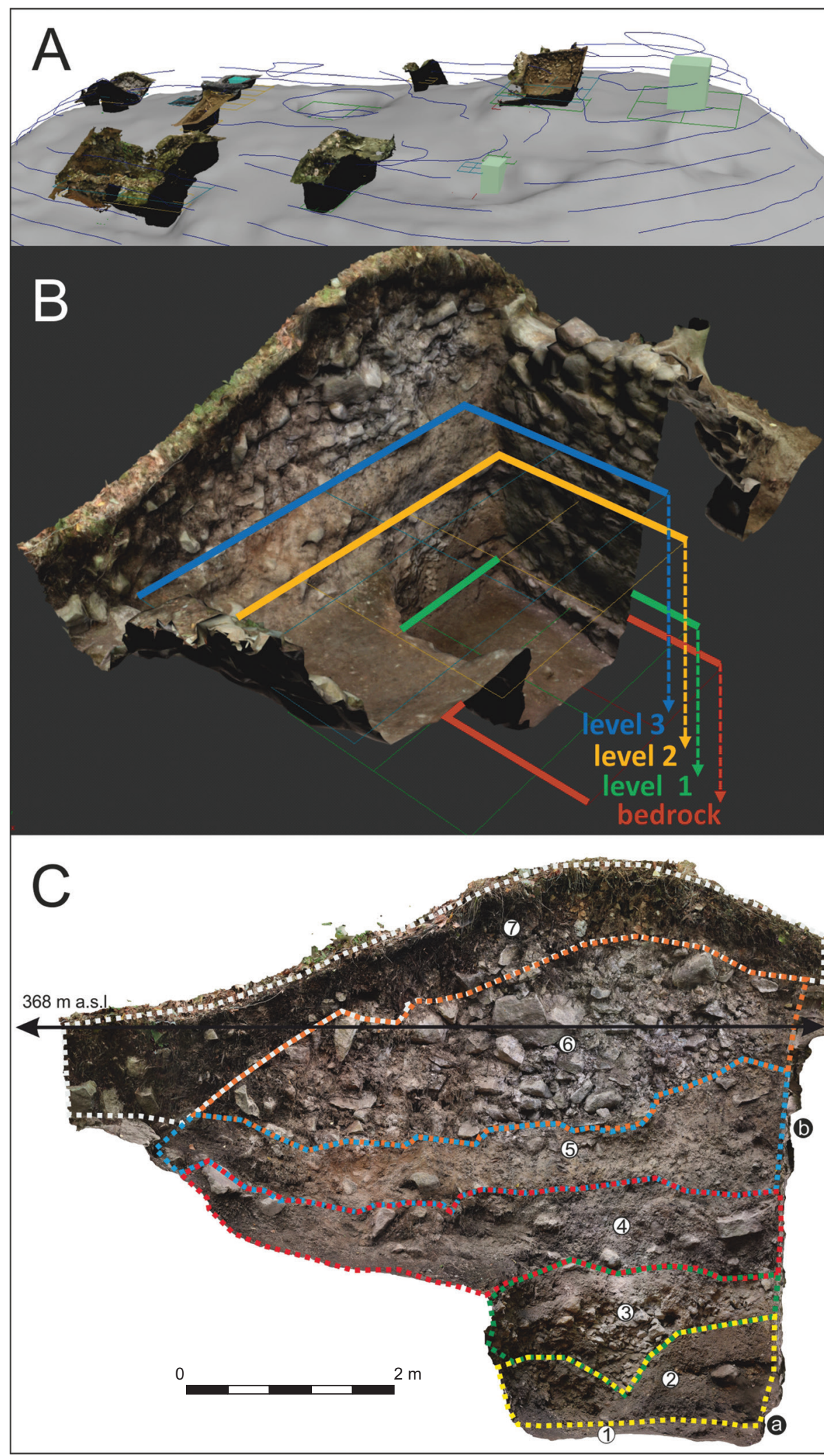

them into the 3D space of the castle hill very accurately (Figure 6). Spatially-situated planes represent auxiliary tools and create a basis for the possible appearance of an original terrain. Based on these planes (bedrock+ levels 1-3), the original terrain was modelled by way of a process of gradually lowering the current terrain to individual levels. An individual terrain model was created for every archaeological level. The result is the identification of 3 phases of original terrain in accordance to the time development of the inhabited castle hill and therefore it represents the constructional activity 
of the castle itself. With this result we can observe major differences in the castle hill relief. As opposed to the current terrain, the original one (level 1) is lower in certain places by $2.5 \mathrm{~m}$ (north corner - trench 1 ) and by $2.8 \mathrm{~m}$ (south corner trench 17). The total volume loss of terrain is some $1700 \mathrm{~m}^{3}$, from current to original terrain level 1. Subsequently, it is possible to differentiate amongst the individual ground walking levels (levels 1-3), which were changing in height over time at their most (west wall - trench 7) by $2.5 \mathrm{~m}$, and at their least by $0.5 \mathrm{~m}$ in the castle complex (trench 2 ). The total volume difference amongst individual levels culminates in a range of 155-195 $\mathrm{m}^{3}$. The subsequent reconstruction of the castle features has been carried out on the $1^{\text {st }}$ and $2^{\text {nd }}$ level, in accordance to the chronological stages of settlement development. Level 3 is considered to be the destruction layer. The horizon of the final destruction of the castle can be identified by a red-black, burnt, clay layers found in multiple locations of the studied trenches (mainly in trenches 1, 2, $9,11,12$, and 19), that possibly point towards a repetitive destructive castle fire. These layers are located just below the debris of the destroyed peripheral wall, thus documenting the final horizon of its existence and the castle's destruction.

\subsection{Fortification}

The fortification is the best preserved and most explored part of the castle. The castle was surrounded around its perimeter by a massive wall rampart, which completely enclosed the area. Before the archaeological excavation, its remains were characterized by a destruction rampart of different heights. On the southern part at the front, the massive debris layer reached a height of nearly $4 \mathrm{~m}$ above the castle grounds. During excavation, it was possible to confirm the continuation of the stone curtain wall on all four sides of the castle grounds (trench 1, 7, 10, 14 and 17). The massive wall rampart with a thickness of around 1.8-2.2 $\mathrm{m}$ is surprisingly well preserved under the layers of debris. The best preserved parts of the inner-facing wall on the southern side reaches a height of nearly $3 \mathrm{~m}$ above the terrain of the castle grounds, in the western part more than $2 \mathrm{~m}$, and in the northern and the eastern parts reaches more than $1.5 \mathrm{~m}$. Excavation also showed that the different heights of the preserved wall, and the debris covering it, is only the result of the varying degree of wall collapse and does not signify its original height. The wall was built using the common medieval technique of masonry alignment into technological lines with a spacing of about $0.6 \mathrm{~m}$ apart. The stone used for its construction possibly came from the immediate surroundings. The presence of visible borrow pits and terrain depressions situated on the southern side of the castle supports this claim. A large part of the stone used for its construction was gained by digging a massive ditch in a cliff made of andesite on the southern side of the castle hill.

The 3D reconstruction of the fortification was mainly based on the interpretation of its construction history (Šimkovic, 2018, pp.33-36), and subsequently based on the 3D models of the trenches and the original terrain's reconstruction. A previously-mentioned review reconstructed the height of walls based on the preserved bases in the above-mentioned trenches. Reconstruction shows that the base of the walls with a thickness of $1.8-2 \mathrm{~m}$ and preserved height in the range of 2-3 m, could have reached at the time of their construction, respective to the period of use of the site, a height of $4 \mathrm{~m}$, and in some places $5 \mathrm{~m}$. In the case of a digitalized find assemblage, auxiliary markers were used - called "anchors", which represented the mass of the wall captured in the individual 3D models of trenches (the exception being trench 17, where the anchor was created based only on the find assemblage documentation, since during the first season, in 2011, 3D documentation was not yet being used). Anchors represented fixed points based on the evidence of the find assemblage, which was linked to the interpretation of the construction history (Figure 7). In the resulting process, the proportion of fortification was adjusted for the original terrain model of level 1. Based on this, we can assume an oval shape for the stone curtain wall on the north and south-west corner. In the case of the south-east corner, we believe that it went through a right angle which respected the rectangular base of the residential tower documented in trench 11. By terrain copying, the wall on the west side must have been significantly extended (more than $6 \mathrm{~m}$ ), as is well

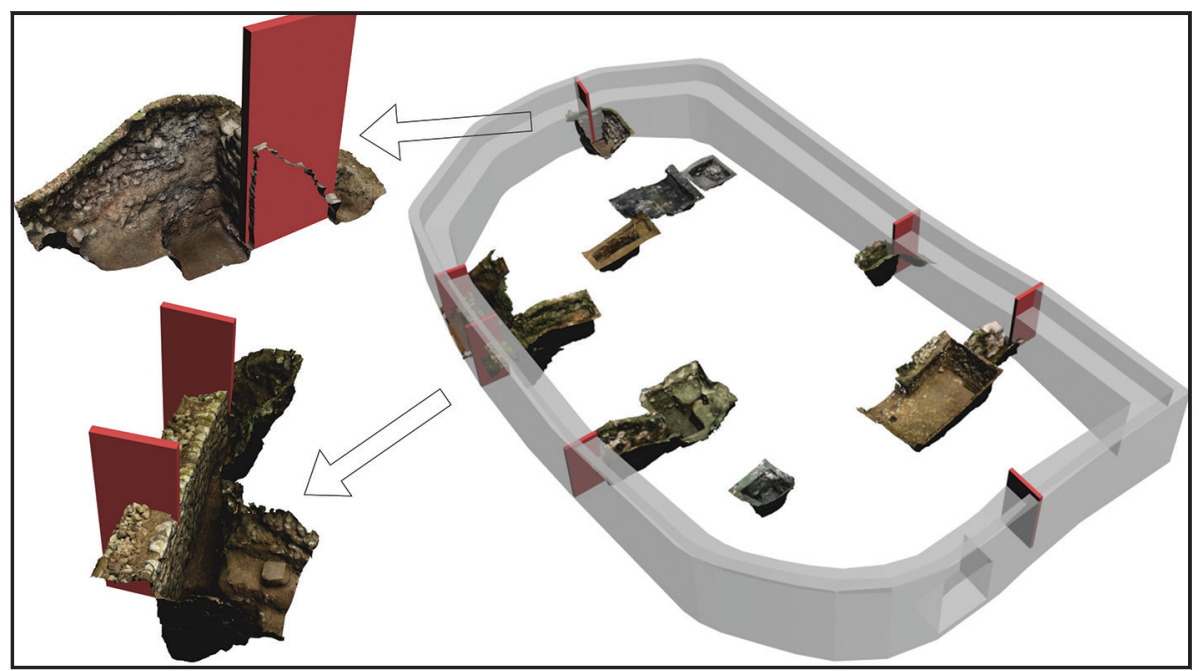

Figure 7. Anchors (red boxes) layout and presumed location of stone fortifications (northeast view). 
documented in trench 7 , and thus its destruction created a significant part of the debris in the courtyard. The extreme differences (ca. $2.8 \mathrm{~m}$ ) between the current terrain level in the southern part of the courtyard and the first walking ground level, confirm the presence of a large part of the preserved wall in these places. An indication of a defensive wall-walk, which started at a height of $4 \mathrm{~m}$ (protected from the outer side by more than $2-\mathrm{m}$ - high battlements) and continued along the entire perimeter of the wall, was an additional part of the wall reconstruction.

\subsection{Structures}

Individual structures were reconstructed based on their find assemblage, reviewing their construction history (Šimkovic, 2018), and by archaeological interpretation. Schematic $3 \mathrm{D}$ models representing the basic proportions of predicted features were created by placing the $3 \mathrm{D}$ trench models into the original castle surroundings (original terrain - level 1 and 2). Using this procedure, a keep, a water tank cistern, buildings of the first phase $-1^{\text {st }}$ terrain level, and buildings of the second phase $-2^{\text {nd }}$ terrain level, were reconstructed.

\subsubsection{Keер}

A compact stone base was gradually uncovered in trench 11 at the southeast corner of the castle grounds; this we interpreted as the base of the inner stronghold of the castle. Its top part was originally made of wood. This stone base has a thickness of $0.5 \mathrm{~m}$ and as confirmed by the excavation, it was gradually built to close the gap with the inner-facing wall of the stone curtain wall. This thus means that the fortification was built first, and was then followed by the stone structure (the base). By way of trench 16 we were able to document the northwest corner of the structure and part of its western end. Both parts were preserved in the form of one masonry row. The corner ended in a right angle (quoin) and was built directly on the bedrock. The range in size of the stone masonry base is indicated by a confirmed length of ca. $8.7 \mathrm{~m}$, and from the northwest corner to the southern inner wall face of the curtain wall a presumed length of max. $9 \mathrm{~m}$. In other words the dimensions of the rectangular base of the keep are around $9 \mathrm{~m}$, allowing us to create a rectangular stronghold with max. base $9 \times 9 \mathrm{~m}$ (Figure 8 ). Based on its disposition, one can assume that it determines the curtain wall continuation in the southeast corner. So far it is not possible to confirm to what extent the fortification was intertwined with the keep's construction (Figure 8: C). Based on the archaeological data, we assume that the structure was wooden while the stone base did not rise greatly above the terrain. Its overall height was specified to $26 \mathrm{~m}$ only by using analogous structures (Plaček and Bóna, 2007). Within trench 11, was identified the bedrock and the walking ground level (Level 1) $0.35 \mathrm{~m}$ above it, which related to the keep's construction. Level 3, located $0.5 \mathrm{~m}$ above level 1 , which represents the destruction horizon, allows us to assume that in this part some extensive

Figure 8. Profile of keep location in the original terrain (level 1). A: orthophoto of trench no. 11 with detail of the tower foundations. B: East profile of trench no. 11 location and position relative to current terrain indicated by blue contour lines. C: south profile of trench no. $11-\mathrm{a}$ : flat surface of tower foundations; b: inner-facing wall of eastern fortification (stratigraphic units: 1 - local burning of the mortar surface; 2 - compact clay layer of pinkish colour; 3 - black carbon layer; 4 - brown clay layer attached to the above-ground face of the wall = level 3; 5 - light-grey layer of sharp-edged quarry stone $=$ destruction of fortifications; 6 - black-grey layer of forest humus).

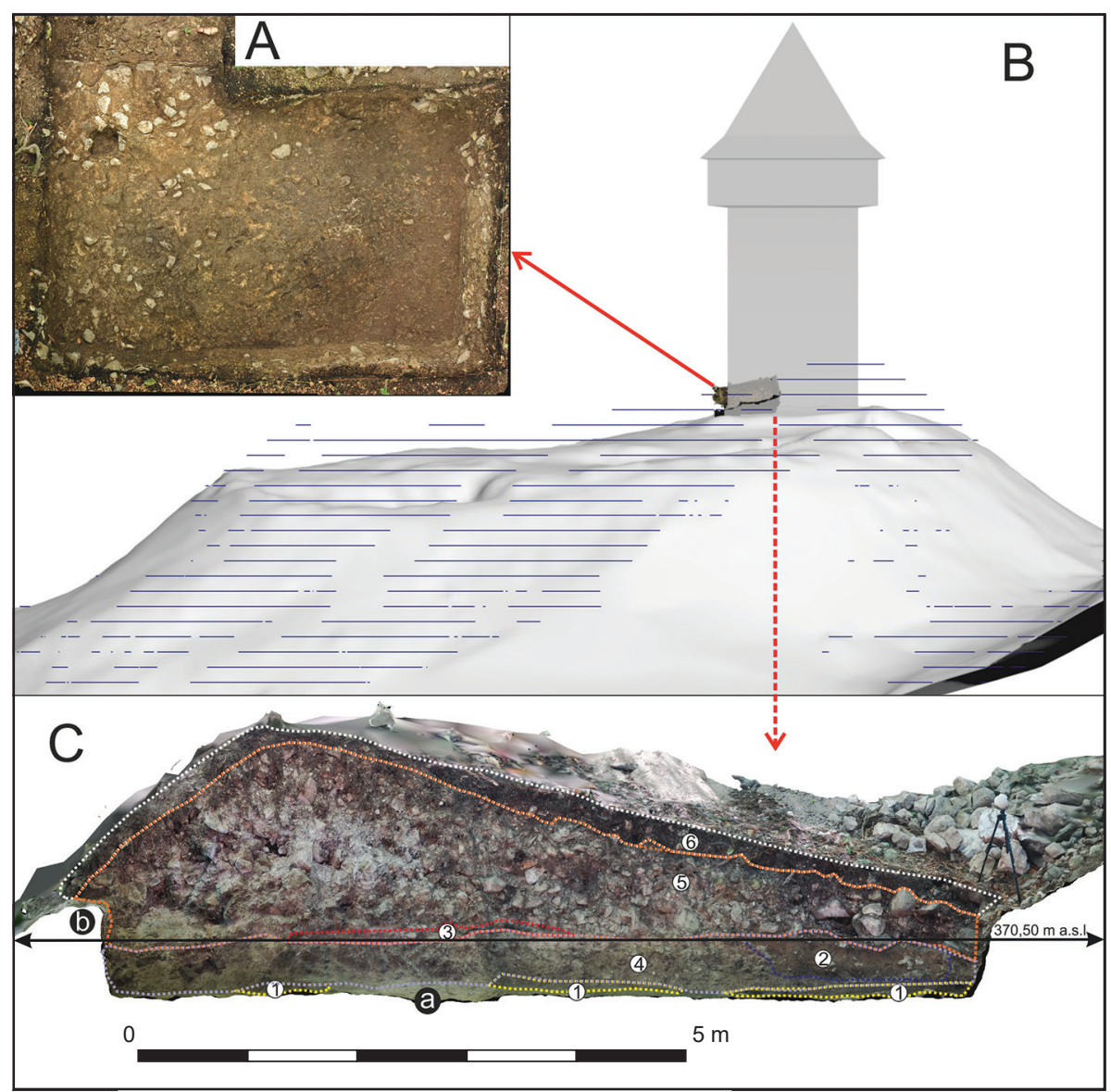


landscaping took place without the presence of the keep. Only above this level did we capture the destruction of the stone curtain wall. Based on the height difference of $0.4 \mathrm{~m}$ at level 1 in trench 11 (keep base) and trench 17 (inner face of the southern part of the curtain wall), we can presume there was a slight $5^{\circ}$ slope in level below the foundations.

\subsubsection{Water tank (cistern)}

In the castle courtyard, a large funnel-shaped depression (almost $10 \times 10 \mathrm{~m}$ ) takes up a dominant position, with its perimeter elevated above the terrain, yet connected to the eastern part of the stone curtain wall. Hanuliak (2006, p.265) considered the depression to be the cellars of a destroyed building or tower. To confirm or disprove this premise, we placed trench 3 with max. dimensions $4 \times 3 \mathrm{~m}$ in the middle of this formation. The research results confirmed that it was originally a water tank (cistern), i.e. a rainwater reservoir in the castle. It was created by cutting more than $3 \mathrm{~m}$ deep into the bedrock. The lining consisted of stone blocks in several layers, while the walls and probably even the bottom were lined with black compact clay to create an impermeable layer. The existence of the tank cistern is now documented only by sporadic findings of carved stone parts with chiselled curved edges, which originally served as parts of the cistern lining. It is not yet clear whether the tank cistern stood as a structure by itself or formed part of another (larger) structure. The walking ground level was documented as being at a height of $367 \mathrm{~m}$ asl. (ca. $1 \mathrm{~m}$ below the current terrain). This parameter corresponds with the documented level in trench 10 located $10.2 \mathrm{~m}$ to the west of the tank cistern. The cistern's dimensions (internal diameter) were created based on the curvature of the retrieved architectural elements. Models corresponding to the individual parts were generated with the help of the 3D documentation of stone blocks. The radius of the cistern's cylindrical shape was determined by the reconstruction of the peripheral boundary made from stone blocks (Figure 9). The overall outer diameter of the cistern was $4 \mathrm{~m}$ with an inner diameter of $3 \mathrm{~m}$. The depth was modelled to match a $3.8 \mathrm{~m}$ depth.

\subsubsection{Structures in the castle courtyard}

Unlike the well-researched fortification, the remains of residential buildings, farm buildings and other structures were less clear. We assume that the courtyard was encircled by clay-wooden structures of varying functionality (economic, manufacturing, residential). Traces of this architecture (post holes made into the stone bedrock, possibly carved bedding trenches, spaces with aligned walls carved into the stone massif, clay-paved "floors") were recorded in the western and northern parts of the courtyard in the close vicinity of the curtain wall. Superpositions recorded in some places indicate that the castle area was reconstructed and altered several times.

\section{Structures of the first phase}

From the inner side of the western part of the fortification within trenches 6,7 and 10, we managed to record aligned spaces carved and cut into the stone massif, which we interpret as inner (cellar?) spaces of originally wooden (or clay-wooden) structures "set" into the inner face of the curtain wall. According to the stratigraphic situation (walking ground level) in trench 10, the structures were built at level 1 at a height $366.5 \mathrm{~m}$ asl.; level 1 being located approximately $3 \mathrm{~m}$ under the floor level of the keep and $1 \mathrm{~m}$ lower than the tank cistern. Since no masonry foundations or walls of some assumed structures were found, we conclude that these were $\log$ houses and/or wooden structures with a base of $5 \times 6 \mathrm{~m}$.

In the southwest corner of the courtyard (trench 15), we managed to record one stone structure/wall that was well preserved to $1.7 \mathrm{~m}$ in height and ca. $1.6 \mathrm{~m}$ wide. It ran in an east-west direction and presumably connected to the inner face of the western part of the curtain wall. The masonry was placed directly on the rock without any base/foundation. On the eastern side it was leaning on a cut down rock section. It was ended by a quoin (corner block), which had been pulled out in the past. Based on the find assemblage, we can assume that the masonry bent towards the south face of the curtain wall; however, this part could not be documented or excavated. Based on the corner orientation of the

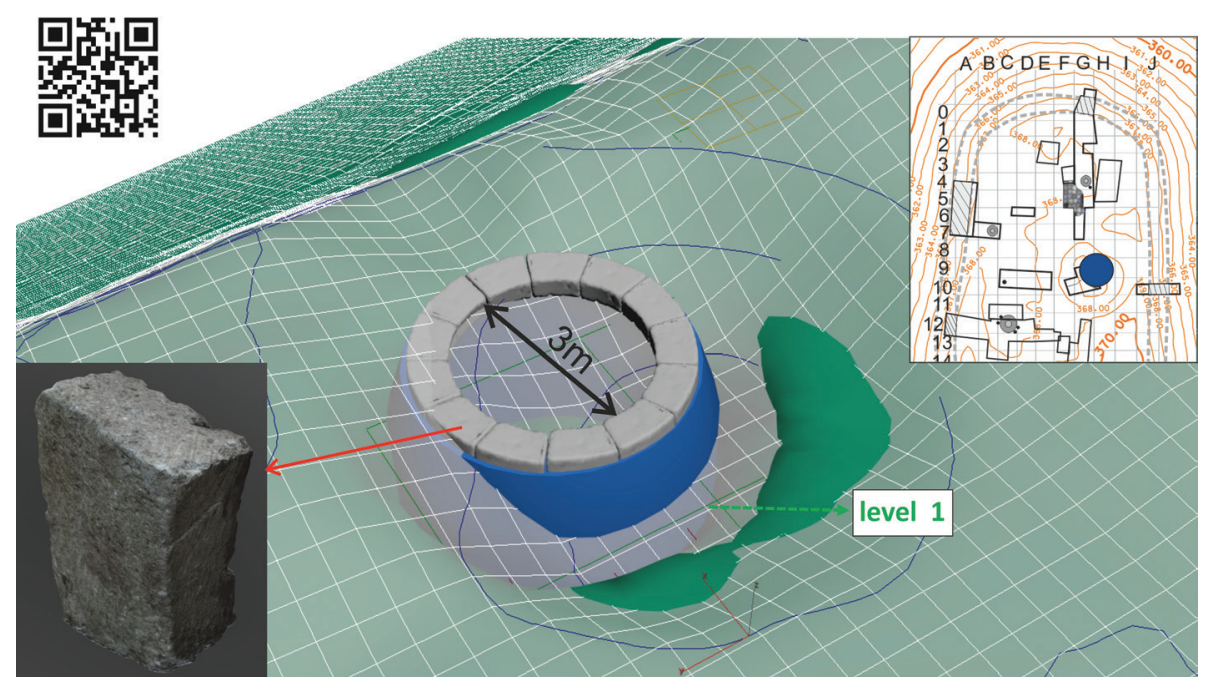

Figure 9. Location of the water tank with a reconstructed stone block rim (green surface represents level 1, grey surface with blue contour lines represents current terrain). QR code to Sketchfab model. 


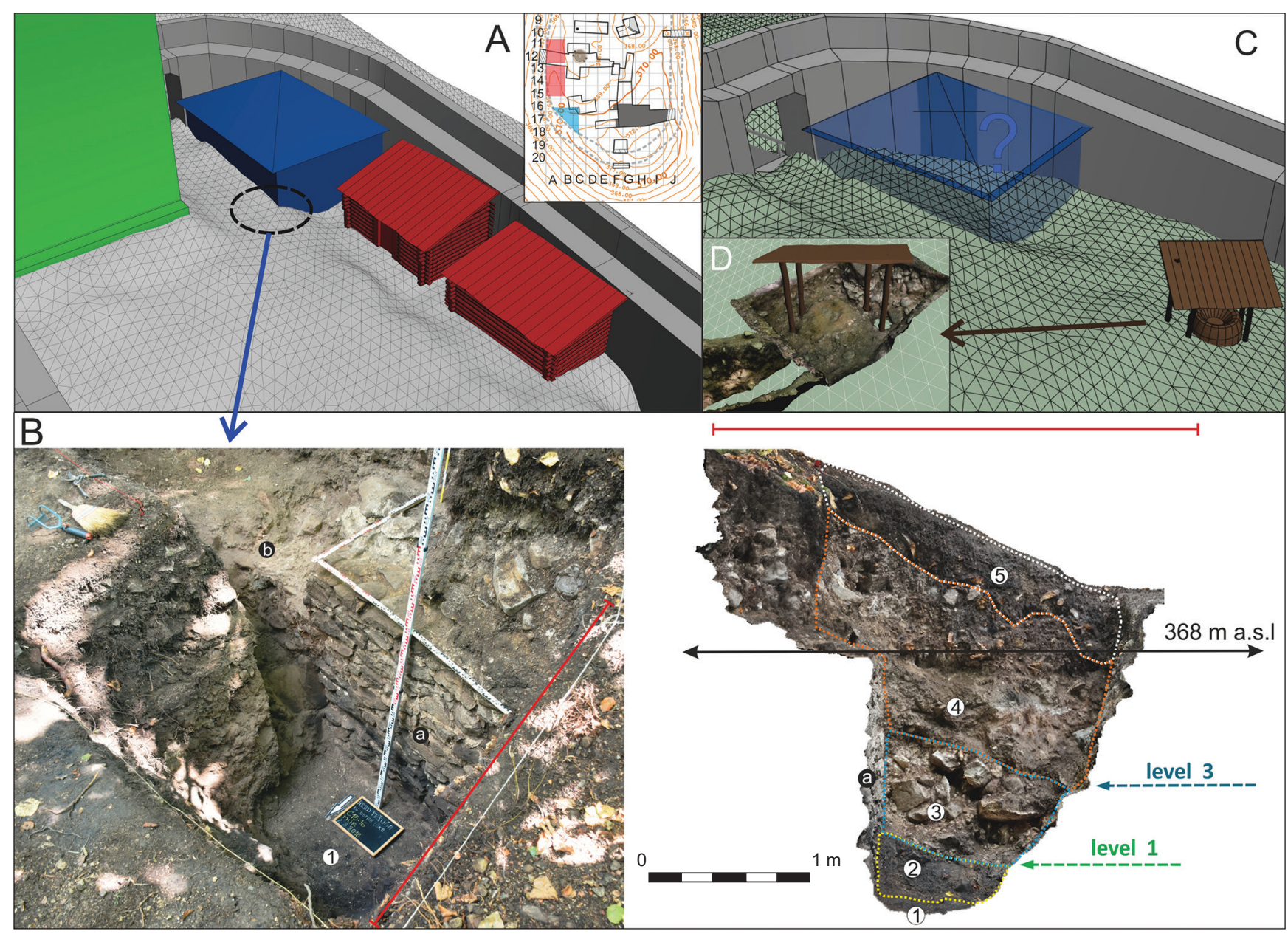

Figure 10. Structures in the courtyard (southwest view). A: location of the first phase structures in the castle area with walking level 1 (grey polygon surface). B: detail of the stone structures in trench no. 15. - overview shot and west profile - a: wall face without a foundation on the bedrock; b: modified/ cut bedrock (stratigraphic units: 1 - modified bedrock $3 \mathrm{~m}$ below current surface; 2 - black, clay, compacted carbon containing layer rich in archaeological finds; 3 - light-grey layer of sharp-edged quarry stone; 4 - light-brown layer of quarry stone; 5 - black-grey layer of forest humus). C: location of the secondphase structures in the castle area with walking level 2 (green polygon surface). D: detail of the installation of columns in trench no. 6.

documented wall and its position with regard to the bedrock, we assume it represents the outer wall of a stone building that was connected to the southwest corner of the curtain wall (Figure 10: A). The captured bedrock is located at a height $366.3 \mathrm{~m}$ asl., thus in approximately the same vertical alignment as level 1 in trench 10 . The distance between the masonry base of the keep (trench 11 and 16) and the corner of the studied masonry wall (trench 15) was $5 \mathrm{~m}$. The distance from the inner face of the curtain wall's southern part to the masonry wall was exactly the same as the distance from the inner face of the curtain wall's southern part to the edge of the keep's stone foundation. Considering its spatial placement, the dimensions of the stone building were $6.2 \times 8.7 \mathrm{~m}$ and between the keep and the stone building there was a corridor up to $5 \mathrm{~m}$ in width and max. $9 \mathrm{~m}$ in length.

Between both features (the keep and the stone building) the walking ground level was probably the same. We base this on the stratigraphic situation in trench 15 , in which we captured the walking ground level $1.2 \mathrm{~m}$ above the bedrock of level 3, connected to the north facade of the stone building
(Figure 10: B). By contrast, on the eastern side of the stone building the carved bedrock is $0.25 \mathrm{~m}$ above level 3 . This superposition points out the placement of the building, which had to be lowered at the north wall and made higher at the east wall through the cut-down bedrock. Thanks to this, the walking ground level, between the stone building, the keep and the southern part of the curtain wall, had a 1-1.2 m higher vertical alignment than the walking ground level of the $\log$ houses located near to the western line of the curtain wall. These facts allowed us to create the offset stepping of the original terrain of the castle courtyard.

\section{Structures of the second phase}

Within trench 6 it was possible to identify, starting from a depth of ca. $0.4 \mathrm{~m}$ from the current terrain, a circular to oval oven ground plan with a diameter of ca. 1.3-1.4 m, with a yellow-brown, clay lining, and in its centre, with a significant amount of loose ash/carbon layer, an oval shape (resembling a fireplace) with max. dimensions of $0.3 \times 0.7 \mathrm{~m}$. The fireplace was slightly dug in and had a bowl-shaped 
profile. The thickness of the feature reached a height of $0.3-$ $0.4 \mathrm{~m}$. It was placed on an artificially-created stone base. The layer of yellow, compact clay (the oven body) was also mixed with bigger (probably fallen) stones, but not enough for us to consider it being a stone-clay oven. Perhaps another oven of a circular shape was placed in trench 2 , but only a yellow-brown clay lining of a circular shape (diameter ca. $1.2 \mathrm{~m}$ ) was identified with no central "fireplace". Near to this feature, a strong layer (thickness up to $0.2 \mathrm{~m}$ ) of burnt charcoal was found. In the case of this smaller (possible) oven, its body was placed directly on the bedrock. In its immediate surroundings, only one post hole (diameter ca. $0.1 \mathrm{~m}$, depth $0.2 \mathrm{~m}$ ) was documented. In the case of the bigger circular "oven" in trench 6, four symmetricallyplaced post holes (diameter $0.2-0.3 \mathrm{~m}$, depth ca. $0.1-0.15 \mathrm{~m}$ ) were found in its vicinity, which could have served as an oven-shelter (Figure 10: D). It is important to note, based on the excavational results, that the oven in trench 6 was in superposition with previous construction(s) and cultural layers (layer depth below the oven was $1.2 \mathrm{~m}$ ). Thus, the oven represented an increase of the terrain to level 2, which influenced the situation in trench 10, where we have assumed the destruction of the wooden/log buildings (Figure 10: C).
The difference in height between walking ground level 1 and 2 in these parts was $0.45 \mathrm{~m}$.

\subsection{Presumed castle entrance}

The archaeological excavation to date has been unsuccessful in finding the entrance gate to the castle. The castle entrance by itself probably consisted of a "simple" door opening in the stone fortification. Some indication of the position of the entrance was documented in trench 7, where two equallycarved, stone architectural elements were documented (segments of wall lining profiled by an inclination to the outer side) in the destruction of the wall debris. These parts could have originally formed a vertical door frame. Even though the inner face of the curtain wall, with a length of almost $7 \mathrm{~m}$ and preserved height of more than $2 \mathrm{~m}$, has been uncovered, the remains of an entrance have not been found.

The entrance of the castle could also be indicated by the access roads. The first access possibility presumes a road leading to the castle from the north down the hill leading from the left bank of the Gran River, where the above-mentioned river ford was located and connected the Pet'uša Castle to the road leading into Zvolen town by the right bank of the river. Unfortunately, the slope of the castle hill from this side is

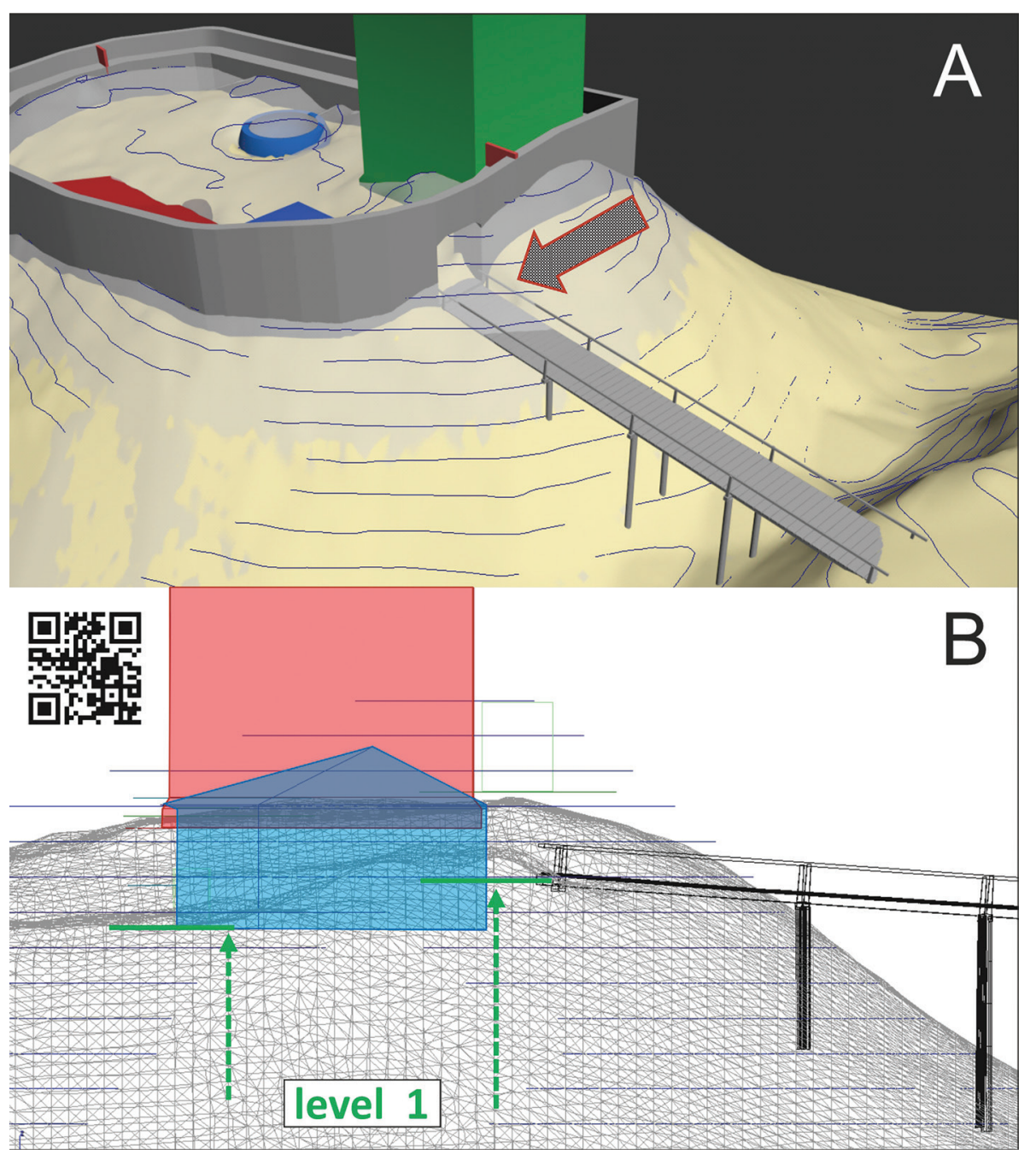

Figure 11. Reconstruction of the castle entrance, hypothesis 1. A: a northeast view of the bridge ditch and the problem with the debris cone (yellow surface represents level 1, grey surface with blue contour lines represents current terrain). B: east profile of the southern part of the castle with a marked keep and a stone building as shown by level 1 discrepancy. QR code to Sketchfab model. 
considerably steep. Even though it is not impossible to reach the castle from this direction, this road is neither the most suitable nor the easiest.

The second possibility would assume the castle entrance to be from the south through the ditch, which could be bridged from the southern terraces. The access road would follow the contour line and would be connected to the crossroads of the previously-mentioned trade routes (Beljak Pažinová, et al., 2013; Slamová et al., 2014; 2016), which led on to the Zvolen area. This assumption was confirmed by LIDAR identification. During the making of a 3D hypothesis for the castle entrance position, the terrain relief and each individual excavated feature were taken into consideration:

$\mathbf{1}^{\text {st }}$ hypothesis: It assumes a secured entrance via a wooden bridge. In this case an entrance gate would be in the southern part of the curtain wall, between the keep and the stone building. The opposite ridge of the terrace is $2 \mathrm{~m}$ lower than the keep's base. With a distance of $23 \mathrm{~m}$ it forms approximately a $3^{\circ}$ slope angle, which would allow for the construction of a bridge of similar length. At the deepest point of the ditch, the bridge would have a height of $5 \mathrm{~m}$. The problem with this hypothesis is the steepness of the south castle hill side and at the same time the problem with the rampart body itself (Figure 11). In order for these conditions of bridge construction to be met, the original terrain near the southern part of the curtain wall would have to be lower by approximately $2-3 \mathrm{~m}$ compared to the current one. In this case the entrance gate and entire entrance corridor would be 1-1.2 $\mathrm{m}$ under the keep base. In the case of the stone building, its eastern wall would have its base only $0.4 \mathrm{~m}$ higher than the walking ground level, while in the north, thanks to the cut-down bedrock, we documented a minimal base height for the stone building masonry of $1.7 \mathrm{~m}$. For this, a stone building of a different construction would have to be created. Otherwise, the stone walls of the building would have to respect the height of the castle entrance and thus the north wall would nearly reach a height of $3 \mathrm{~m}$.

$2^{\text {nd }}$ hypothesis: It assumes that the castle could have been entered without a bridge. At the same time, this hypothesis is based on the important stratigraphic situation in trench 15 . The surface level determined by the curtain wall base could suggest the castle entrance to be located in the western line of the fortification (Figure 12: B). For this way, the cut-down bedrock documented on the north facade of the stone building is valid. In this case, besides the stone building, during phase one, only one other wooden building would have existed located on the opposite side of the gate. An entrance platform would correlate with level 1 and gradually lead to the higher vertical alignment under the keep. On the other hand, there is still the question of an access road, which would have to

Figure 12. Reconstruction of the castle entrance, hypothesis 2. A: east profile of the castle hill with a modified access road. $\mathrm{B}$ : detail of the stone building foundation in trench no. 15. C: display of an alternative access path.

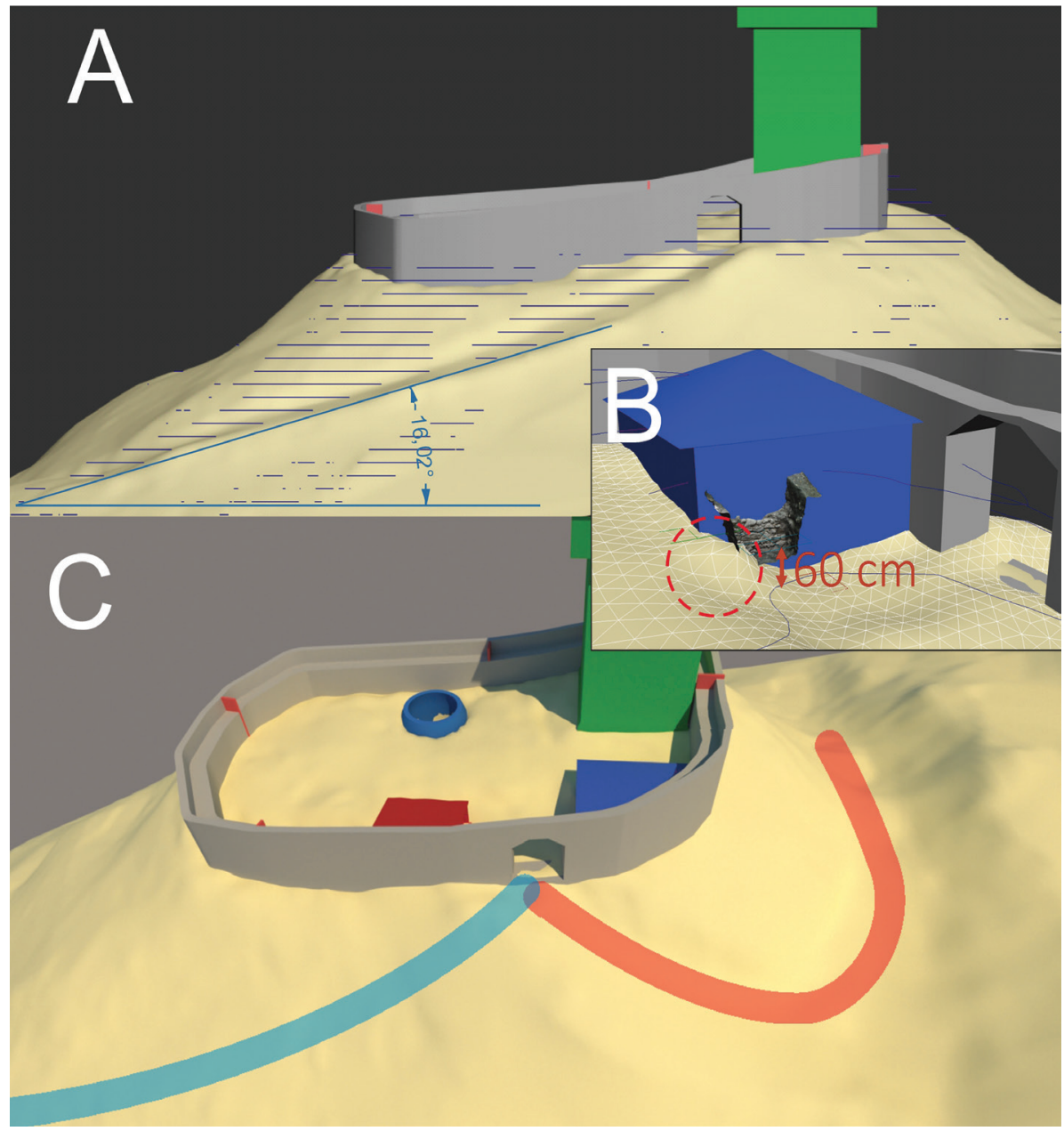


be located on the castle foothills. A less severe variant still counts with an average hill slope of $16^{\circ}$, which raises doubts regarding the effective accessibility to the castle and opens up other possibilities for an access linked with the search for an adequate road leading from the Gran River ford to the castle (Figures 12: A and C).

\section{Results and discussion}

The targeted systematic archaeological excavation of the Pet'uša Castle allowed us to get relevant information regarding the shape of the castle's core from the $13^{\text {th }}$ to the $15^{\text {th }}$ century. Based on the visible terrain relicts, as well as the excavated remains of the fortification, we managed to determine the dimensions of the establishment. Even though the castle entrance has not yet been localized, we have some major indication of its whereabouts and the application of interdisciplinary research has allowed us to identify a probable access road. Thorough terrain research has helped us to picture the constructional evolution of the castle, even though the state of the preserved above-ground architecture of the castle courtyard is minimal. The majority of the walls were taken apart and building stone probably reused in different places. Excavation has proved that some parts of the curtain wall, keep base, masonry wall of the stone building, and some parts of the cistern façade, are still (to a certain extent) preserved. Thanks to the use of 3D technology, we have achieved a more thorough and exact reconstruction of the building phases than with the "simpler" use of a common descriptive and graphic evaluative form of finding contexts within individual trenches. We should emphasise that, in this case, we have applied the method to a greater extent by including individual features, the terrain relief, and the fortification within one castle complex. Regarding the 3D technology, the documentation processes and $3 \mathrm{D}$ reconstruction was combined in such a way that it created exact three-dimensional documentation and transparent interpretation, represented by the multiple hypothesises.

The use of 3D technology is especially advantageous in complex areas and Pet'uša Castle is undoubtedly such a case. The correlation of stratigraphic relations over such a big area between numerous excavational trenches at different points of the castle complex, can be easily overlooked, even marginalized. The height attributes of individual contexts themselves are often considered insufficiently and processed inefficiently. That's why we consider a clear specification of the documentation to be an important positive aspect of this approach, which includes spatial (in terms of the absolute dimensions of the models) as well as qualitative data (in terms of the detailed textures). 3D model-layering of individual contexts significantly lowers the loss of information during the excavation and allows for a (partial) re-access to the excavation in a software environment. Considering the time span over which the excavation took place, the data collection methodology could not be considered as consistent as one would like, and we can therefore only contemplate the full use of this method. The transfer of the entire finding documentation into 3D space allowed for a better orientation of spatial relations of individual contexts without the need of some generalization from mathematical models. In the future, an effective and very beneficial method seems to be the retroactive modelling of the original terrain (the terrain during multiple phases), which gives a realistic look at the historical conditions not just from the perspective of the buildings layout, but also a modelling of the life within the castle and the reconstruction of the historical surroundings. Thank to this method, we have tried to solve some dispositional questions connected to the features, the fortification and the castle entrance. Many, still unverified, possibilities lie in the evaluation of visibility, archaeoacoustics, and sunlight simulation.

Our main goal in the application of $3 \mathrm{D}$ reconstruction was to extend the interpretation base through the creation of multiple hypothesises. This could be followed by more open and informative discussions concerning individual conclusions, thanks to the direct evidence obtained through modelling of the evaluated situations. On the other hand, it is necessary to point out a few of the disadvantages resulting from these procedures. An obvious one is the greater time and technical difficulty, which is significant when compared to traditional methods. However, in modern archaeology, even more complex spatial methods are currently being used, which present similar demands on the researcher. The second significant disadvantage is the frequent problem with idealization, which relates to the visualization of archaeological structures. A conflict occurs in situations where we can exactly describe the spatial and formal attributes of certain elements (e.g. a wall base, fireplaces, construction foundations) whereas, with other elements, their attributes can only be derived (spatial attributes from terrain situations and formal ones by analogy). Hence some combined or compound features must inevitably be reconstructed with a certain level of abstraction, and visualized in such a way so that known aspects and assumed aspects can be easily distinguished. The appropriate solution is to graphically distinguish the hypothetical parts (monochrome, or using transparent construction), which on the one hand brings a more objective presentation of the results, but on the other hand suppresses the potential expression of the graphical outputs. Naturally the presentation is not the primary intention and therefore it is appropriate to work with this form of output only in specific phases of the research. A more serious problem may be the purpose of the reconstructed models themselves, which (even in those cases of greatest certainty) are only predicted - and yet can, in subsequent steps, represent a truer and more informative picture than the results gained solely from more formalized procedures.

\section{Conclusion}

It should be stressed that there are many factors which can significantly alter the site's inherent appearance (including 
the composition of finds) during the castle's activity, as well as after its abandonment. Also, our knowledge is significantly affected by the current state of research. The understanding and reconstruction of the medieval settlement, its visualization and day-to-day running, is a multidisciplinary issue - within which the results of the archaeological excavations and construction-history research, together with the study of the material culture, represent one part of a whole.

Thanks to the use of $3 \mathrm{D}$ technology we were able to better understand the original castle space and dynamically capture the changes in usage of the castle complex. Part of the analysis was not only the modelling of features and stone architecture, but also the modelling of the multiple levels of the original terrain. The conjunction of archaeological outputs gathered from the excavated trenches and the 3D models of the current terrain has proven to be an efficient method. By applying a recognized stratigraphy into a $3 \mathrm{D}$ space, along with the subsequent modification of the terrain, we were able to create multiple phases of settlement with respect to the building phases and the adjacent profile of the terrain. Thanks to this, multiple levels of hypothesises regarding the inner-built environment, as well as the castle entrance, could be formulated.

The next important step will be a comparison of other settlements in the region, and later on in the central European region. The precise analysis of all the components of the material culture will gradually bring reliable results for creating an idea of the historical life of the researched castle. Even though the Pet'uša Castle represents only a small source of knowledge in the research of medieval life, it is an important precedent for Slovakia in the uniqueness of its research execution and interpretation of results.

\section{Acknowledgments}

This work was supported by the Slovak Research and Development Agency under the contract No. APVV-170063. Also, we would like to thank Michal Styk for the English translation of the article.

\section{References}

ASPÖCK, E., and FERA, M., 2015. 3D-GIS für die taphonomische Auswertung eines wiedergeöffneten Körpergrabes. Journal für Angewandte Geoinformatik, 1, 2-8.

BARCELÓ, J.A., 2000. Visualizing what might be. An introduction to Virtual Reality in Archaeology. In: J.A. Barceló, M. Forte, and D. Sanders, eds. Virtual Reality in Archaeology. BAR International Series, 843, Oxford: ArcheoPress, pp. 9-36.

BELJAK, J. et al., 2014. Pustý hrad vo Zvolene. Dolný hrad 2009 - 2014. Zvolen - Nitra: Univerzita Konštantína Filozofa v Nitre.

BELJAK, J., BELJAK PAŽINOVÁ, N., and ŠIMKOVIC, M., 2018. Pustý hrad vo Zvolene a hrad Petuša vo svetle aktuálnych výskumov. $1^{\text {st }}$ ed. Zvolen: Mesto Zvolen.
BELJAK PAŽINOVÁ, N. 2017. Petuša castle from the high middle ages. Vrcholnostredoveký hrad Pet'uša. Archaeologia historica, 42(2), 453467.

BELJAK PAŽINOVÁ, N., and RAGAČ, R., 2018. Pet'uša Castle: An aristocratic seat or a toll station? Comparison of archaeological and historical sources. Hrad Pet’uša - šl'achtické sídlo alebo mýtna stanica? Konfrontácia archeologických a historických prameňov. Archaeologia historica, 43(1), 187-201.

CALLIERI, M., et al., 2011. Documentation and Interpretation of an Archaeological Excavation: an experience with Dense Stereo Reconstruction tools. In: M. Dellepiane, et al., eds. The $12^{\text {th }}$ International Symposium on Virtual Reality, Archaeology and Cultural Heritage VAST (2011). Eurographics Association, pp. 33-40.

DELLEPIANE, M., et al., 2013. Archeological excavation monitoring using dense stereo matching techniques. Journal of Cultural Heritage, 14(3), 201-210

FORTE, M., 2008. Cyber-archaeology: An eco-approach to the virtual reconstruction of the past. In: $14^{\text {th }}$ international conference on virtual systems and multimedia. Larnaca.

FORTE, M., 2010. Introduction to Cyber-Archaeology. In: M. Forte, ed. Cyber-Archaeology. BAR International Series, 2177. Oxford: BAR Publishing, pp. 9-14.

GARSTKI, K., ARNOLD, B., and MURRAY, M.L., 2015. Reconstituting community: 3D visualization and early Iron Age social organization in the Heuneburg mortuary landscape. Journal of Archaeological Science, 54, 23-30.

GRUBER, E., 2015. 3D Models as Analytical Tools. In: B.R. Olson, W.R. Caraher, and S. Heath, eds. Visions of substance: $3 D$ imaging in Mediterranean archaeology. North Dakota: The Digital Press, pp. 63-68.

HANULIAK, V., 2006. Vojenské pevnosti Jána Jiskru vo Zvolene. Militärische Festung des hussitischen Feldherrn Jan Jiskra in Zvolen. Archaeologia Historica, 31, 259-268.

HERCEG, P., and MAZÚR, R., eds., 2018. Zachráñme hrady: záchrana historických ruín občianskymi združeniami v rokoch 2002-2017. Bratislava: Združenie zachráňme hrady.

HIRSCHMULLER, H., 2008. Stereo Processing by Semiglobal Matching and Mutual Information. IEEE Transactions on Pattern Analysis and Machine Intelligence, 30(2), 328-341.

MALINIAK, P., 2009. Človek a krajina Zvolenskej kotliny v stredoveku. Banská Bystrica: Filozofická fakulta, Univerzita Mateja Bela, Banská Bystrica.

PALIOU, E., 2014. Visibility analysis in 3D built space: a new dimension to the understanding of social space. In: U. Liebewirth, and S. Polla, eds. Spatial analysis and social spaces. Interdisciplinary approaches to the interpretation of prehistoric and historic built environments. Berlin, Boston: De Gruyter, pp. 91-113.

PAŽINOVÁ, N., et al., 2013. Stredoveká cestná siet' v okolí Zvolenského Pustého hradu: analýza na základe antropogénnych reliéfnych foriem. Študijné Zvesti Archeologického ústavu Slovenskej Akadémie vied, 54, $153-170$.

PLAČEK, M., and BÓNA, M., 2007. Encyklopedie slovenských hradů. $1^{\text {st }}$ ed. Praha: Libri.

SLÁMOVÁ, M., et al., 2014. Dependence of the Medieval Settlements and Historical Roads to the Natural Environment Around the Deserted Castle in Zvolen (Slovakia). Procedia - Social and Behavioral Sciences, 120, 213-223.

SLÁMOVÁ, M., et al., 2016. Multidisciplinary approach to research on historical landscape structures. In: L. Halada, A. Bača, and M. Boltižiar, eds. Landscape and Landscape Ecology. Proceedings of the $17^{\text {th }}$ International Symposium on Landscape Ecology, 27-29 May 2015, Nitra, Slovakia. $1^{\text {st }}$ ed. Bratislava: SAV, pp. 176-184.

ŠIMKOVIC, M., 2018. Hrad Pet'uša, k.ú. Ostrá lúka. Architektonickohistorický výskum murív odkrytých archeologickým výskumom. Unpublished expert survey. Deposited at Department of Archaeology, Constantine the Philosopher University in Nitra. 
